Article

\title{
Sedimentary Record of Cladoceran Functionality under Eutrophication and Re-Oligotrophication in Lake Maggiore, Northern Italy
}

\author{
Liisa Nevalainen $^{1, *(1)}$, Meghan Brown ${ }^{2}$ and Marina Manca ${ }^{3}$ \\ 1 Ecosystems and Environment Research Programme, Faculty of Biological and Environmental Sciences, \\ University of Helsinki, Niemenkatu 73, 15140 Lahti, Finland \\ 2 Department of Biology, Hobart and William Smith Colleges, 4095 Scandling Center, Geneva, NY 14456, USA; \\ mbrown@hws.edu \\ 3 CNR Institute of Ecosystem Study, Largo Tonolli 50, 28922 Verbania, Italy; m.manca@ise.cnr.it \\ * Correspondence: liisa.nevalainen@helsinki.fi; Tel.: +358-2941-20311
}

Received: 20 December 2017; Accepted: 16 January 2018; Published: 19 January 2018

\begin{abstract}
We examined fossil Cladocera (Crustacea) communities and their functional assemblages in a 60-year sediment record from Lake Maggiore, northern Italy. Our main objective was to document the response of aquatic community functioning to environmental stress during eutrophication (1960-1985) and recovery (post-1985), and to identify environmental controls on cladoceran functionality. Of the functional groups, large filter feeders and oval epibenthos thrived prior to eutrophication (reference conditions pre-1960) and globular epibenthos and small filter feeders increased during eutrophication and as the lake recovered. Multivariate analyses suggested that bottom-up controls (i.e., total phosphorus) were important for shaping functional assemblages but taxonomic community changes were likely related to top-down control by predators, particularly the predaceous cladoceran Bythotrephes longimanus. Functional diversity (FD) was higher and Daphnia ephippia length (DEL) larger during the reference and early eutrophication periods and decreased during eutrophication and recovery. Both FD (high) and DEL (large) were distinct during reference period, but were similar (FD low, DEL small) between the eutrophication and recovery periods. The functional attributes and the assemblages did not recover post-eutrophication, suggesting that the system exhibited a clear shift to low FD and dominance of small filterers. Cladoceran functionality appears to be related to fundamental ecosystem functions, such as productivity, and may thus provide insights for long-term changes in ecological resilience.
\end{abstract}

Keywords: biodiversity; environmental change; fossil Cladocera; functional diversity; paleolimnology; ecological resilience; subalpine lakes

\section{Introduction}

Nutrient enrichment of freshwaters is a worldwide challenge [1]. In combination with intensified climate warming, these anthropogenic changes threaten aquatic biodiversity and ecosystem services [2,3]. Ecological communities and their responses to environmental stressors, such as eutrophication in aquatic systems, can be investigated with a functional approach, where interest is put on species' ecological roles. For example, feeding traits, habitat preferences, reproduction, or morphological attributes (e.g., body size) can reflect certain ecological functions [4]. The concept of functionality in ecological communities allows a comprehensive understanding of how environmental changes alter ecosystems through biological functions rather than just taxonomic composition [5]. This kind of mechanistic approach on aquatic systems may reflect important ecosystem level processes, for example, changes in productivity and trophic structure of lakes. In the functional approach, functional diversity (FD) is a biodiversity measure, 
which takes into account the variety of biological functions of species and may allow for a more holistic understanding of environmental changes and ecosystem responses $[4,6]$.

With major losses in global biodiversity [7], paleolimnological data sets can aid our understanding of the relationships among functional diversity and ecosystem productivity, climate change, and trophic dynamics [8-10]. Since key members of aquatic communities (or their traces) are preserved as fossils in lake sediments, paleolimnology can be used to evaluate ecosystem functions and ecological resilience in lakes. Further, lake sediment archives are advantageous for functional classification and ecosystem level responses to environmental changes, because time lags often prevent detection during short-term observations [11,12].

Here, we continue the application of paleolimnological research on Lake Maggiore in northern Italy (Figure 1) to investigate the lake as a "natural laboratory" with its well-documented history of eutrophication and re-oligotrophication during the last century. This subalpine lake is Italy's second largest and deepest lake and part of the long-term limnological monitoring in Europe [13]. Naturally oligotrophic and phosphorus-limited Lake Maggiore eutrophied in the 1960s as a result of nutrient loading from the catchment and wastewater discharge [14,15]. Phosphorus concentrations started to increase and the peak of nutrient enrichment occurred during the late 1970s when total phosphorus at winter mixing $\left(\mathrm{TP}_{\text {mix }}\right)$ was $31 \mu \mathrm{g} \mathrm{L}^{-1}$ and the lake became mesotrophic (Figure 2). After that, due to enhancements in wastewater treatment, recovery of the lake proceeded and TP decreased back to oligotrophic levels $\left(\sim 10 \mu \mathrm{g} \mathrm{L}^{-1}\right)$ during the early 1990s. Previous research on Lake Maggiore plankton has indicated that the aquatic communities are highly responsive to nutrient status, trophic dynamics, and climate [15-18]. For example, Lake Maggiore zooplankton has exhibited major changes in taxonomic composition, body size, and population density under eutrophication and re-oligotrophication $[15,17,18]$.

a)

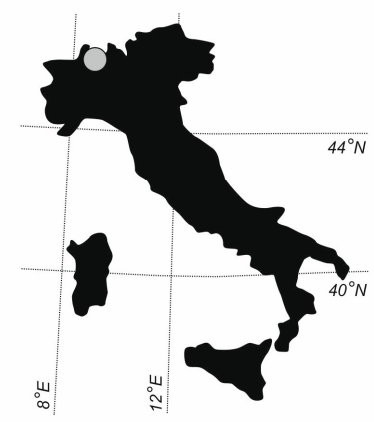

b)

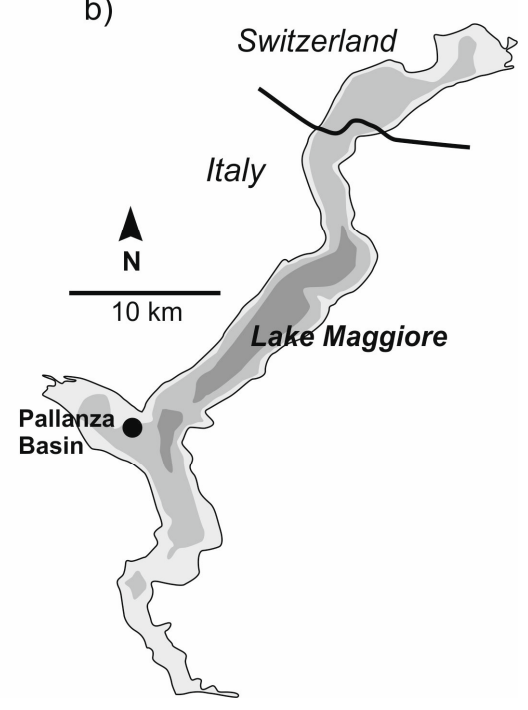

Figure 1. (a) Location of Lake Maggiore in northern Italy (gray dot) and (b) location of the sediment core sampling site in the Pallanza Basin of Lake Maggiore (black dot), where the shades of gray represent bathymetric details (light gray $<100 \mathrm{~m}$, mid gray 100-300 m, and dark gray $>300 \mathrm{~m}$ water depth).

The aim of the current research was to examine responses to eutrophication and the subsequent limnological recovery of Lake Maggiore by the cladoceran communities. We analyzed fossil cladoceran communities for their taxonomic composition, functional characterization, and functional attributes of FD and Daphnia ephippia length (DEL) in a sediment core covering the years of pre-eutrophication, eutrophication and recovery (1944-2010). We aimed to identify the main environmental forcings on the long-term succession of cladoceran communities, functional assemblages, and functional attributes, 
and discuss the roles of bottom-up versus top-down controls in ecosystem functioning during the eutrophication and re-oligotrophication of Lake Maggiore.

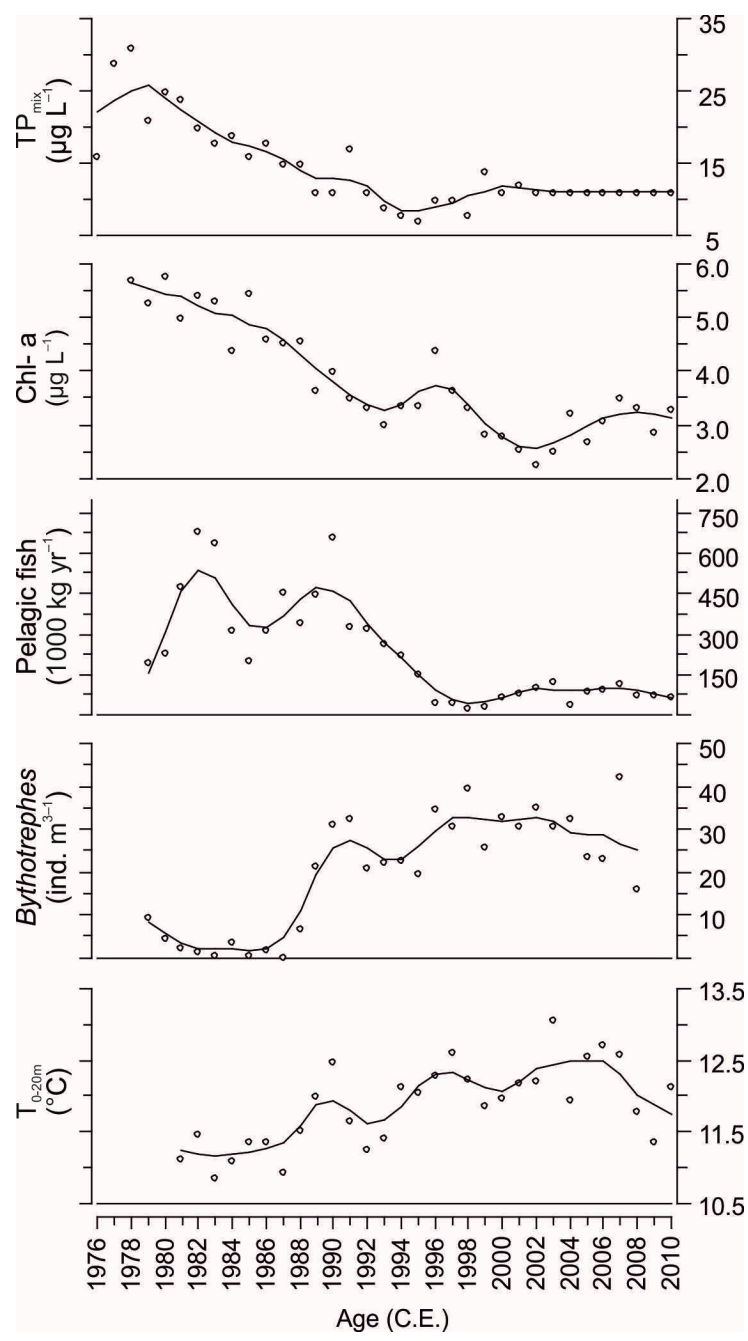

Figure 2. Real time observations in the long-term changes in Lake Maggiore total phosphorus at winter mixing (TP ${ }_{\text {mix }}$, since 1976), chlorophyll-a concentration (Chl- $a$, since 1978), pelagic fish catch (since 1979), Bythotrephes longimanus abundances (1979-2008) and water temperature of the euphotic zone 0-20 $\mathrm{m}\left(\mathrm{T}_{0-20 \mathrm{~m}}\right.$, since 1981). These data are previously partly published [15,18].

\section{Materials and Methods}

A modified Wilco box corer (liner internal surface area $28 \mathrm{~cm}^{2}$, shaft depth $50.5 \mathrm{~cm}$ ) was used to collect a 34-cm core in the Pallanza Basin of Lake Maggiore ( $45^{\circ} 54.76$ N, $\left.8^{\circ} 32.96 \mathrm{E}, \mathrm{z}=98 \mathrm{~m}\right)$ on 11 February 2010 (Figure 1). The intact core was stored dark at $4{ }^{\circ} \mathrm{C}$ until processing. The core was vertically sliced at $1-\mathrm{cm}$ intervals and the outer edge of each segment was discarded. A $10 \mathrm{~g}$ subsample was removed from each interval for ${ }^{137} \mathrm{Cs}$ dating at University of Applied Sciences (Holland). Increases in the ${ }^{137} \mathrm{Cs}$ activity were interpreted as increased fallout of ${ }^{137} \mathrm{Cs}$ from nuclear activity (Figure 3a). An age-depth model was created by interpolating the surface sediment sample $\left(0 \mathrm{~cm}\right.$, year 2010), increased ${ }^{137} \mathrm{Cs}$ activities of Chernobyl fallout (1986) at $14 \mathrm{~cm}$, and the nuclear weapons testing horizon (1963) at $25 \mathrm{~cm}$ (Figure 3b). As the model is based on constant sedimentation rate between these time horizons it should be interpreted cautiously. 


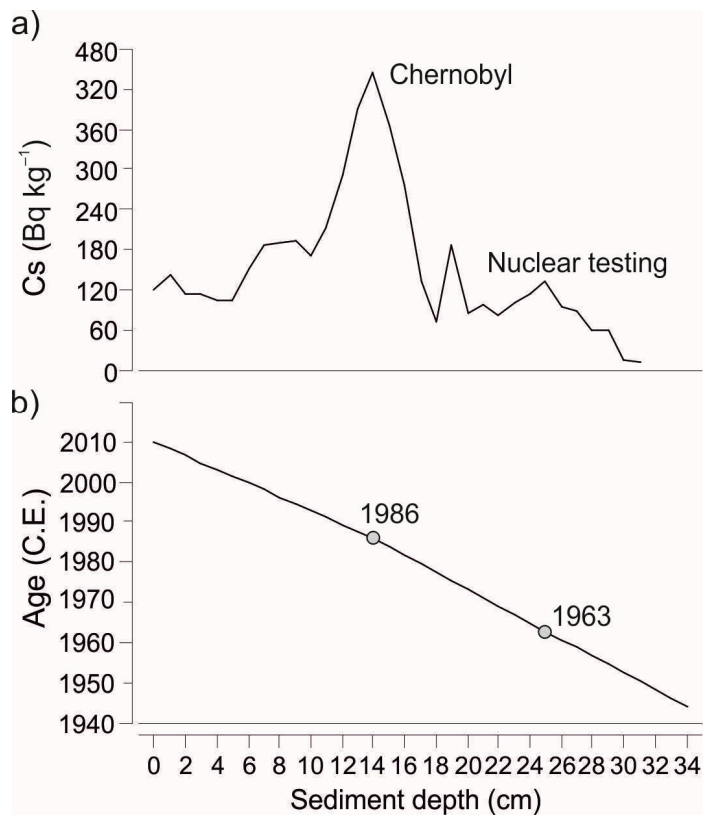

Figure 3. (a) ${ }^{137} \mathrm{Cs}$ activity and (b) an age-depth model for the Lake Maggiore sediment core. Peak activities of Chernobyl nuclear disaster (year 1986) and nuclear weapon testing (1963) are indicated.

The remaining portion of each sediment interval was prepared for fossil Cladocera analysis following the standard methods [19]. First, the samples were heated in $10 \% \mathrm{KOH}$ to deflocculate sediment and then sieved through a $76-\mu \mathrm{m}$ mesh, which is adequate to retain cladoceran zooplankton fossil remains and the remains of smallest taxa of Chydoridae (e.g., Alonella nana and Coronatella rectangula, Table 1). The residue was stained pink with safranine. The fossil Cladocera remains (carapaces, headshields, postabdomens and ephippia) were identified and enumerated with a light microscope (magnifications 100-400X) and the most abundant body part was chosen to represent the number of individuals of each species. A minimum of 100 fossil individuals were counted from each subsample. Relative abundances of individual taxa were used to determine the community composition in the core samples. In addition, to examine functional characterization of the community (i.e., functional assemblages) taxa were assigned to the groups (Table 1): predators, large filter feeders, small and intermediate filter feeders (hereafter small filterers), globular epibenthos, and oval epibenthos based on a previous functional grouping of Cladocera [10]. Size (i.e., body length) from base to apex (spine excluded) of encountered fossil Daphnia ephippia was measured with a Zeiss microscope at 100X magnification equipped with a camera and analyzed with Image pro express 5 software to estimate the mean Daphnia ephippia length (DEL). Ephippia were measured from 32 sediment samples and number of size measurements per sediment subsection varied from 1 to 73 (mean 13).

Principal component analysis (PCA) was used to summarize temporal succession of cladoceran taxonomic communities (compositional gradient $<1.5 \mathrm{SD}$, standard deviation units) and functional assemblages $(<1.0 \mathrm{SD})$. The response data were square root transformed for PCA. In addition, redundancy analysis (RDA) was used to analyze relationships between functional assemblages and cladoceran taxonomic communities and limnological variables during the period of continuous environmental monitoring (since 1978). Chlorophyll- $a$ concentration (chl- $a$ ), total phosphorus at winter mixing $\left(\mathrm{TP}_{\text {mix }}\right)$, water temperature of the euphotic zone 0-20 $\mathrm{m}\left(\mathrm{T}_{0-20 \mathrm{~m}}\right)$, Bythotrephes longimanus abundance, and total pelagic fish catch were included as environmental variables (Figure 2). Environmental variables were forward selected and the significance $(p \leq 0.05)$ of each variable was tested with Monte Carlo permutations (999). Cladoceran functional diversity (FD) was evaluated with Rao's FD index [20], i.e., Rao's quadratic entropy. For the index, each cladoceran taxa was assigned 
with qualitative functional character including body size (small $<500 \mu \mathrm{m}$, intermediate 500-1000 $\mu \mathrm{m}$, large $>1000 \mu \mathrm{m}$ ), body shape (elongated, oval, globular), feeding type (filterer, scraper-detritivore, predator) and microhabitat (pelagic, benthic, attached to vegetation, Table 1) [10]. This characterization was based on ecological data available for cladoceran taxa [21,22] and the characters were inserted as functional character present (1) and absent (0). Multivariate analyses (PCA and RDA) and analysis of FD were performed with Canoco 5 software [23]. Tukey's pairwise comparisons were utilized to indicate differences in FD and DEL during the reference (pre-1960), eutrophication (1960-1985), and recovery (post-1985) periods. These analyses were performed with PAST software [24]. Segmented regression analysis was utilized to detect statistically significant breakpoints (minimum confidence level of 95\%) in FD and DEL. The best breakpoint was selected based on maximizing the statistical coefficient of explanation and performing tests of significance with SegReg program [25].

Table 1. Functional characterization of cladoceran taxa (indicated with asterisks) encountered from Lake Maggiore sediment core based on body size ( $\mathrm{S}=$ small, $\mathrm{M}=$ intermediate, $\mathrm{L}=$ large), body shape ( $\mathrm{G}=$ globular, $\mathrm{O}=$ oval, $\mathrm{E}=$ elongated $)$, feeding type $(\mathrm{F}=$ filterer, $\mathrm{S}-\mathrm{D}=$ scraper-detritivore, $\mathrm{P}=$ predator, including parasitism), and habitat $(\mathrm{P}=$ pelagial, $\mathrm{B}=$ benthic, $\mathrm{V}=$ vegetation) and their functional grouping (FG) used in Figure 4. Among each functional group, the taxa are listed according to their mean relative abundance from the most abundant at the top.

\begin{tabular}{|c|c|c|c|c|c|c|c|c|c|c|c|c|c|}
\hline & \multicolumn{3}{|c|}{ Body Size } & \multicolumn{3}{|c|}{ Body Shape } & \multicolumn{3}{|c|}{ Feeding Type } & \multicolumn{2}{|c|}{ Habitat } & \multirow[b]{2}{*}{$\mathrm{V}$} & \multirow[b]{2}{*}{ FG } \\
\hline & $S$ & $\mathrm{M}$ & $\mathrm{L}$ & G & $\mathrm{O}$ & $\mathrm{E}$ & $\mathrm{F}$ & S-D & $\mathrm{P}$ & $\mathrm{P}$ & $\mathrm{B}$ & & \\
\hline Leptodora kindtii & & & $*$ & & & $*$ & & & * & $*$ & & & Predator \\
\hline Sida crystallina & & & $*$ & & * & & $*$ & & & * & & $*$ & Large filterer \\
\hline Daphnia longispina-type & & & $*$ & & * & & $*$ & & & $*$ & & & Large filterer \\
\hline Eubosmina longispina-type & & * & & * & & & $*$ & & & * & & & Small filterer \\
\hline Eubosmina coregoni-type & & * & & * & & & $*$ & & & $*$ & & & Small filterer \\
\hline Bosmina longirostris & * & & & * & & & $*$ & & & $*$ & & & Small filterer \\
\hline Chydorus cf. sphaericus & * & & & * & & & & * & & * & & $*$ & Globular epibenthos \\
\hline Paralona pigra & * & & & $*$ & & & & * & & & $*$ & & Globular epibenthos \\
\hline Pleuroxus uncinatus & & * & & * & & & & * & & & $*$ & $*$ & Globular epibenthos \\
\hline Monospilus dispar & * & & & $*$ & & & & * & & & $*$ & & Globular epibenthos \\
\hline Alonella excisa & * & & & * & & & & * & & & $*$ & $*$ & Globular epibenthos \\
\hline Pleuroxus trigonellus & & * & & $*$ & & & & * & & & $*$ & $*$ & Globular epibenthos \\
\hline Alonella exigua & * & & & * & & & & * & & & & $*$ & Globular epibenthos \\
\hline Alonella nana & * & & & * & & & & * & & & $*$ & $*$ & Globular epibenthos \\
\hline Anchistropus emarginatus & & * & & * & & & & & $*$ & & $*$ & $*$ & Globular epibenthos \\
\hline Alona affinis & & * & & & * & & & * & & & $*$ & $*$ & Oval epibenthos \\
\hline Alona quadrangularis & & * & & & * & & & * & & & $*$ & & Oval epibenthos \\
\hline Acroperus harpae & & * & & & * & & & * & & & $*$ & $*$ & Oval epibenthos \\
\hline Eurycercus spp. & & & $*$ & & * & & & * & & & $*$ & $*$ & Oval epibenthos \\
\hline Alona guttata & * & & & & * & & & * & & & $*$ & * & Oval epibenthos \\
\hline Camptocercus rectirostris & & & $*$ & & * & & & * & & & $*$ & $*$ & Oval epibenthos \\
\hline Disparalona rostrata & & * & & & * & & & * & & & $*$ & & Oval epibenthos \\
\hline Peracantha truncata & & * & & & * & & & * & & & $*$ & $*$ & Oval epibenthos \\
\hline Coronatella rectangula & * & & & & * & & & * & & $*$ & $*$ & $*$ & Oval epibenthos \\
\hline Alona intermedia & * & & & & * & & & * & & & $*$ & $*$ & Oval epibenthos \\
\hline Graptoleberis testudinaria & & * & & & * & & & * & & & & * & Oval epibenthos \\
\hline Pleuroxus laevis & & * & & & * & & & * & & & $*$ & * & Oval epibenthos \\
\hline Alona rustica & & * & & & * & & & * & & & $*$ & * & Oval epibenthos \\
\hline Alona guttata f. tuberculata & * & & & & * & & & * & & & $*$ & $*$ & Oval epibenthos \\
\hline Rhyncotalona falcata & * & & & & * & & & * & & & $*$ & & Oval epibenthos \\
\hline
\end{tabular}




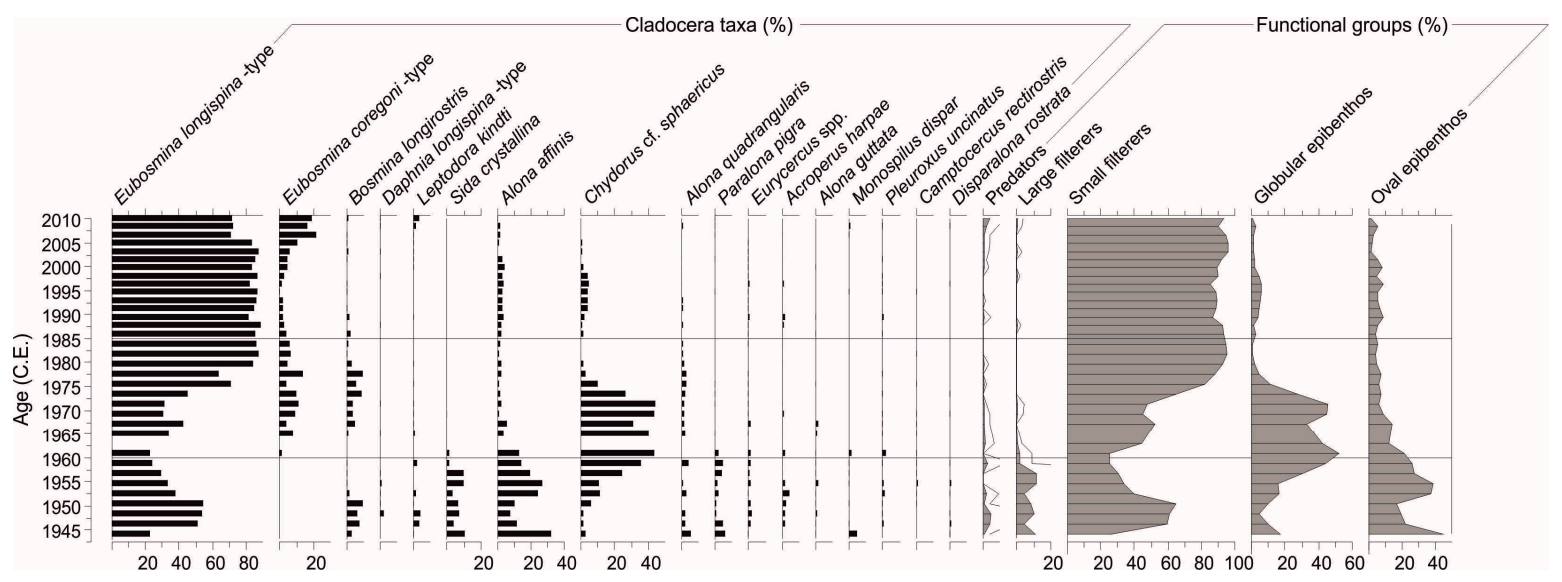

Figure 4. Relative abundances of most abundant fossil cladoceran taxa and functional groups in Lake Maggiore sediment core. The horizontal lines define the reference (pre-1960), eutrophication (1960-1985), and recovery (post-1985) periods.

\section{Results}

We detected 30 cladoceran taxa in the Lake Maggiore sediment core (Table 1). The most abundant taxa were Bosminidae, including Eubosmina longispina-type ( $n=34$, mean percent abundance $63.5 \%)$, Eubosmina coregoni-type $(n=26,5.7 \%)$, and Bosmina longirostris $(28,2.6 \%)$ and Chydoridae (chydorids), including Chydorus cf. sphaericus ( $n=31,11.3 \%$ ) and Alona affinis ( $n=34,6.7 \%)$. In the early core (until 1960s; reference period) the communities were dominated by A. affinis and E. longispina-type ( 60\%) together with lower abundances of $B$. longirostris, Leptodora kindtii, Sida crystallina and several less common chydorids (e.g., Alona quadrangularis, Paralona pigra, Eyrycercus spp. and Acroperus harpae; Figure 4). Chydorus cf. sphaericus started to increase in the early 1960s and reached maximum abundance $(\sim 40 \%)$ and dominance during early 1970s. Bythotrephes longimanus, which were abundant in zooplankton samples starting in the 1990s (Figure 2), were not detected in the fossil community (Table 1). In functional assemblages, succession proceeded from oval epibenthos during pre-1960s to globular epibenthos ( 40-50\%) between 1960 and 1975, and small filterers (80-90\%) after that until the top core (Figure 4). Predators and large filterers were scarce $(<10 \%)$ and occurred mostly prior to 1960 s.

PCA for cladoceran taxonomic communities resulted in eigenvalues 0.514 for PCA axis 1 and 0.217 for PCA axis 2. Cumulative percentage of variance explained by the PCA were $51.4 \%$ and 73.2\% for PCA axes 1 and 2, respectively. Samples in the reference period (pre-1960) had positive PCA axis 1 scores with increasing PCA axis 2 scores (Figure 5a). Samples from the eutrophication period (1960-1985) had reducing scores along PCA axes 1 and 2. Recovery period samples (post-1985) clumped together at the negative end of PCA axis 1. PCA for functional assemblages had eigenvalues of 0.763 for PCA axis 1 (cumulative \% of variance 76.3 ) and 0.169 for axis $2(93.2 \%)$. Sample scores drifted from positive axis 2 values to negative prior to 1960 and from positive to negative axis 1 values during eutrophication (Figure 5b). Most recent samples of the recovery period had negative axis 1 values and close to zero axis 2 values.

RDA for functional assemblages resulted in eigenvalues 0.222 for RDA axis 1 and 0.1585 for axis 2 and all the environmental variables explained $40.6 \%$ of the variance in the assemblages. RDA identified $\mathrm{TP}_{\text {mix }}(38.3 \%)$ as the single significant $(p<0.05)$ environmental factors explaining variance in functional assemblages (Table 2). RDA for taxonomic communities resulted in eigenvalues 0.2158 and 0.0778 for axes 1 and 2, respectively and forward selection did not results in any statistically significant results (Table 2). Bythotrephes longimanus abundances, however, explained most variance in the communities with $33.4 \%(p=0.0600)$. 
a)

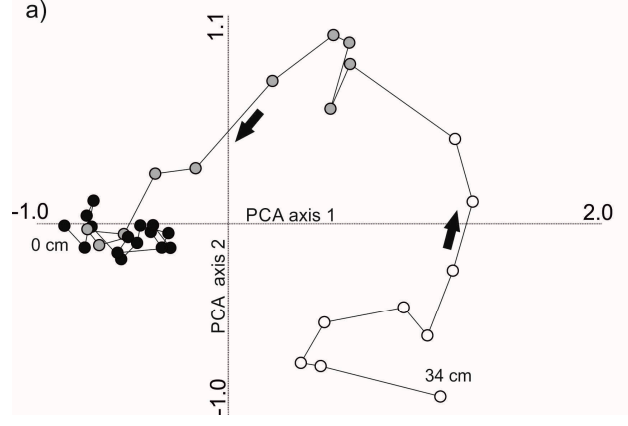

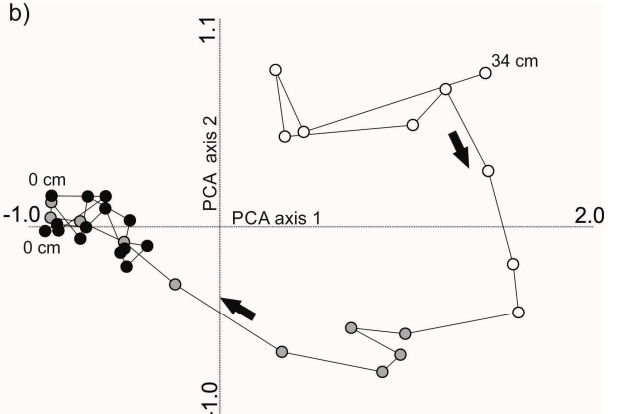

Figure 5. Principal component analysis (PCA) ordination diagrams for (a) cladoceran communities and (b) functional assemblages, where white symbols = reference period (pre-1960), gray symbols = eutrophication period (1960-1985), and black symbols = recovery (post-1985). The top (0 cm) and bottom $(34 \mathrm{~cm})$ samples of the core are marked, the black lines connect sample points chronologically, and the arrows indicate the direction of change.

Table 2. Forward selection statistic (\% explained, F- and $p$-values) of environmental variables (see abbreviations in Figure 2) in redundancy analysis (RDA) applied separately for cladoceran functional assemblages and taxonomic communities (and percentage of variance explained by all environmental variables) in Lake Maggiore since the period of continuous environmental monitoring. Most significant environmental variables are marked in bold type.

\begin{tabular}{ccc}
\hline & $\begin{array}{c}\text { Functional Assemblages } \\
\mathbf{( 4 0 . 6 \%} \text { Explained by All Var.) }\end{array}$ & $\begin{array}{c}\text { Taxonomic Communities } \\
\mathbf{( 3 8 . 7 \%} \text { Explained by All Var.) }\end{array}$ \\
\hline $\mathrm{TP}_{\operatorname{mix}}$ & $\mathbf{3 8 . 3 \%}(\boldsymbol{F}=\mathbf{2 . 5 8}, \boldsymbol{p}=\mathbf{0 . 0 3 9 )}$ & $13.2 \%(F=0.85, p=0.515)$ \\
Chl- $a$ & $23.7 \%(F=1.67, p=0.183)$ & $12.2 \%(F=0.77, p=0.569)$ \\
Bythotrephes & $19.6 \%(F=1.43, p=0.247)$ & $\mathbf{3 3 . 4} \%(F=\mathbf{2 . 1 3}, \boldsymbol{p}=\mathbf{0 . 0 6 0 )}$ \\
$\mathrm{T}_{0-20 \mathrm{~m}}$ & $16.0 \%(F=1.19, p=0.327)$ & $20.3 \%(F=1.33, p=0.220)$ \\
Fish & $2.35 \%(F=0.16, p=0.954)$ & $20.9 \%(F=1.23, p=0.242)$ \\
\hline
\end{tabular}

FD varied between 1.7 and 3.2 in Rao's FD index (Figure 6). The highest FD occurred in the early core until 1960 after which FD decreased until the early 1980s. FD increased slightly between 1990 and 2000 but was reduced post-2000. DEL measurements varied between 470 and $690 \mu \mathrm{m}$ (Figure 6). DEL was largest $(\sim 650 \mu \mathrm{m})$ in the early to mid-core until 1970s and then started to decrease and remained consistent $(\sim 550 \mu \mathrm{m})$. Tukey's test indicated significant differences in FD and DEL between reference and eutrophication periods, and reference and recovery periods (Table 3). No significant differences in FD or DEL were found between eutrophication and recovery periods. SegReg identified single significant breakpoints for FD at $15.64 \mathrm{~cm}$ (early 1980s) and DEL at 20.14 (early 1970s, Figure 6).

Table 3. Tukey's pairwise comparisons (Q-value, $p$-values in brackets) of cladoceran functional diversity (FD) and mean Daphnia ephippia length (DEL) between periods of recovery (pre-1960), eutrophication (1960-1985), and recovery (post-1985). Statistically significant differences are marked in bold type.

\begin{tabular}{cccc}
\hline & Recovery & Eutrophication & Reference \\
\hline Recovery & - & {$[$ DEL] $1.965(0.360)$} & {$[$ DEL] 7.828 $(<\mathbf{0 . 0 0 1})$} \\
Eutrophication & {$[$ FD] 3.371 $(0.059)$} & - & {$[$ DEL] 5.863 $(<0.001)$} \\
Reference & {$[$ FD] 11.23 $(<\mathbf{0 . 0 0 1 )}$} & {$[$ FD] 7.863 $(<\mathbf{0 . 0 0 1 )}$} & - \\
\hline
\end{tabular}




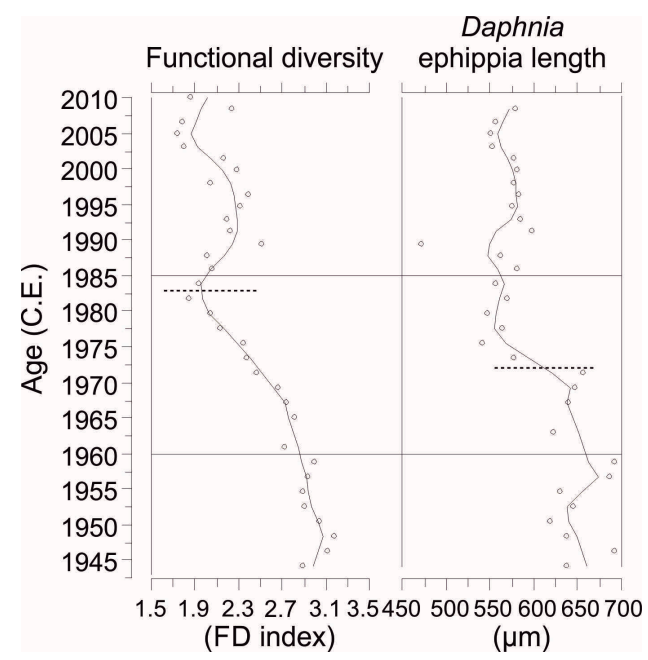

Figure 6. Cladoceran functional diversity (FD) and mean Daphnia ephippia length in the Lake Maggiore sediment core. The horizontal lines define the reference (pre-1960), eutrophication (1960-1985), and recovery (post-1985) periods, and the dashed horizontal lines represent segmented regression breakpoints.

\section{Discussion}

Bottom-up (food, habitats) and top-down (predators) controls drive cladoceran communities in Lake Maggiore, based on trophic dynamics inferred from sediments dating from 1943 to 2002 [17]. Here we present more refined functional analysis and include the most recent decade of fossil records (1944-2010). Cladoceran communities succeeded from Alona affinis to Chydorus cf. sphaericus, and later to Eubosmina longispina-type dominance with a functional shift from large filterers (e.g., Sida, Daphnia) and oval epibenthos (e.g., A. affinis) to globular epibenthos (C. cf. sphaericus) and most recently to small filterers (Eubosmina, Figure 4). The biotic changes occurred gradually and even prior to the eutrophication as small filterers and epibenthos exhibited shifts prior to 1960s but predators and large filterers responded promptly at $\sim 1960$ (Figure 4). This suggests that there was a difference in timing of the response among the functional groups and species, likely related to changed resources just prior to major nutrient loading. The PCAs indicated a clear temporal shift in the taxonomic communities and functional assemblages through the reference-eutrophication-recovery phases with a new stable state during the recent years of re-oligotrophication (Figure 5). The opposite drift of PCA axis 2 scores in taxonomic (from negative to positive scores, Figure 5a) and functional assemblages (from positive to negative, Figure $5 b$ ) during the reference-early eutrophication may suggest that diverse control mechanisms drove changes in taxonomic vs. functional communities. In agreement, RDA forward selection statistics suggest that functional assemblage shifts were associated with bottom-up controls (Table 2), since they were mainly predicted by $\mathrm{TP}_{\text {mix }}$ during the time period of the core covered by limnological monitoring (since late 1970s, Figure 2). Taxonomic communities were best explained, although only marginally significant, with top-down control, i.e., Bythotrephes abundance (Table 2). Bythotrephes is known to regulate zooplankton, especially Daphnia as its main prey item, in Lake Maggiore and impact their distribution, abundance and phenology $[18,26,27]$.

In general, caution should be taken when applying the ecological patterns reported here as whole-lake patterns, as the current sediment core was sampled from the Pallanza Basin (Figure 1). Nevertheless, the trends reported here are consistent with the previous research from another core [17]. Fossil remains (e.g., mandibles, caudal spines, resting eggs) of Bythotrephes longimanus, although abundant in zooplankton samples in Lake Maggiore (Figure 2, also in the Pallaza Basin), were not detected from the current core (Table 1) or in the previous sediment-based research [17] and the reason for that remains unexplained. Typically, Bythotrephes remains (caudal spines and sometimes resting eggs) are well recovered from sediments and their accumulation has been used to estimate presence and abundance [28-31]. Bythotrephes 
remains have been found from sediments in large and deep subalpine lakes, such as Lake Garda in northern Italy [32], in similar type of geo-limnological settings than Lake Maggiore. The use of a larger (76- $\mu \mathrm{m})$ than the commonly used $\sim 50-\mu \mathrm{m}$ sieve [19] for processing sediment samples for fossil cladoceran analysis in the current study is not a reasonable explanation for the lack of Bythotrephes remains, since the previous studies have used even a 250- $\mu \mathrm{m}$ aperture sieve [28-30]. Accordingly, it may be that the sediment sampling site in the Pallanza Basin was not a representative location for Bythotrephes fossils to preserve. It is further possible that some still unidentified limnological factor in Lake Maggiore prevents Bythotrephes fossils for preserving in the sediments.

Functional assemblages of the Lake Maggiore core succeeded from epibenthos to small filterer dominance during the eutrophication and re-oligotrophication (Figure 4). Globular epibenthos increased in conjunction with eutrophication succession around 1970s. This group is mainly formed by a single dominant taxon (C. cf. sphaericus), whose feeding is characterized by fine-mesh filtering [33]. It is adapted to diverse resources of detrital food (detritus and attached microbes) and pelagic habitats under eutrophic conditions [34,35] and has been reported to occur at high abundances during the eutrophication period of Lake Maggiore [17]. A stable functional phytoplankton community dominated by large-celled groups was present during the late eutrophication and early recovery [15]. Clear responses of the phytoplankton communities to reduced nutrients started to occur during late 1980s when small-sized phytoplankton groups increased in the lake [15]. The functional succession in Lake Maggiore zooplankton toward small planktonic filterers (i.e., Eubosmina) may have been partly related to the more efficient grazing of these small sized planktonic cladocerans under low-density food conditions [36,37], i.e., oligotrophic conditions. However, relying on the current chronology (Figure 3), functional assemblages of Cladocera responded earlier than the phytoplankton (late 1980s) to nutrient reductions as small filterers increased already during the early 1980s (Figure 4) [15]. Therefore, it is likely that the shifts in functional assemblages in Lake Maggiore were also affected by varying vulnerability of different functional groups to predation and were partly driven by top-down controls, although not identified by the RDA (Table 2). Pelagic fish abundances increased in the early 1980s (Figure 2) and fish tend to prey on largest and most visible prey [38] fitting with the increase of small filterers in Lake Maggiore.

We detected a significant breakpoint in FD during the early 1980s (segmented regression breakpoint, Figure 6), which occurred in conjunction with the lowering trend in $\mathrm{TP}_{\text {mix }}$ at the turn of the decade (Figure 2). FD started to decline during the 1960s under eutrophication, whereas it was highest during the pre-eutrophication period suggesting a negative relationship between lake productivity and FD (Figure 6). Contrasting results were found from small and shallow boreal lakes in Finland [10], where FD of cladocerans experienced a long-term positive relationship with eutrophication until mesotrophic conditions (TP $\sim 40-60 \mu \mathrm{g} \mathrm{L}^{-1}$ ). The cause for such a positive relationship was apparently diversifying niche space in both pelagic and littoral habitats until mesotrophic conditions, but after which deterioration of littoral-benthic resources reduced FD [10]. A different niche space pattern (i.e., high niche space during low productivity and vice versa) may explain the negative FD-productivity relationship in Lake Maggiore during the eutrophication. This variable pattern is likely related to divergent habitat diversity dynamics in large and deep subalpine vs. small and shallow boreal lakes. For example, the littoral zones, with highest and most diverse niche space, of deep and steep basin morphology and transparent oligotrophic waters of Lake Maggiore may reduce rapidly by even slight changes in primary production and consequent changes in the euphotic zone depth. There exists a positive zooplankton FD-ecosystem function relationship in experimental systems [39] and, despite the geographical differences, the paleolimnological evidence from natural lake ecosystems and cladoceran fossils support the FD-ecosystem function (e.g., productivity) relationship.

The current DEL data series of Lake Maggiore can be considered to represent an estimate of a mean Daphnia ephippium size in the past. It should be interpreted with caution because ephippia were absent or scarce in some sediment samples because Daphnia was mostly parthenogenetic during the mesotrophic status in Lake Maggiore (M. Manca, unpublished data). DEL was larger during 
the pre-eutrophication conditions and reduced under eutrophication and was separated by a clear threshold in the early 1970s (segmented regression breakpoint, Figure 6). The limnological monitoring does not extend continuously back to 1970 s but $\mathrm{TP}_{\text {mix }}>30 \mu \mathrm{g} \mathrm{L}{ }^{-1}$ were recorded during the late $1970 \mathrm{~s}$ (Figure 2). Previously, it has been suggested that Daphnia body size decreases during eutrophication and increased abundance of planktivorous fish [40] fitting well with the Maggiore DEL data. From the bottom-up point of view, DEL development and its reduction was likely related to changes in food quality for Daphnia under oligotrophic conditions and competition with Bosminidae that are better adapted to low food levels and small-sized phytoplankton [36,37]. However, the breakpoint in DEL does not match with the planktonic rearrangement that took place in Maggiore during the 1980s [15] but precedes it with almost a decade suggesting that DEL was likely under top-down control.

Paleolimnological records on FD are valuable, but scarce, to understand ecosystem functionenvironmental stress interconnections and tipping points $[10,12]$. In connection with ecosystem function, the use of FD indices can indicate ecosystem resilience under environmental perturbations, such as eutrophication or climate warming. Since our Lake Maggiore core did not reach actual pre-disturbance conditions before any significant human impact, it is difficult to assess the natural level and fluctuation of FD as fish introductions started already in the 19th century. There was a regime shift visible in functional assemblages and attributes in the current record around 1980, suggesting a shift in ecosystem status that was evident also in the environmental data with reductions in primary production (Figure 2) and planktonic algal communities [15]. This was evident for cladoceran communities described in previous investigations, where a completely new community composition prevailed after eutrophication [17]. The functional assemblages have yet to return to pre-eutrophication conditions and the functional changes appear to be irreversible. In combination, FD and DEL did not return to pre-eutrophication high values and did not differ significantly during eutrophication and recovery phases (Figure 6, Table 3) suggesting that, despite reduced nutrient status, diversity and ecosystem functioning exhibited a new state.

The observed changes in functional attributes (Figures 4 and 6), even though principally explained by productivity in Lake Maggiore, may also include a signal of climate-induced shifts. Climate change may be difficult to decouple from those of eutrophication and re-oligotrophication in Lake Maggiore since some previously reported functional changes, e.g., dominance of smaller phytoplankton can also be explained by warming lake water in addition to re-oligotrophication [15], and these two environmental changes overlap temporally. Previous results from high alpine lakes have shown that limnological consequences of climate warming, e.g., deepening of thermocline and increasing water temperature may induce functional changes in cladocerans and reduce their FD [12]. Accordingly, thermal changes in the water column of Lake Maggiore, e.g., increasing epilimnetic water temperatures (Figure 2) or deeper thermocline, may be, at least in part, responsible for the functional changes, e.g., increase and dominance of small filter feeders and low FD.

In conclusion, FD and DEL had negative relationships with nutrient status in Lake Maggiore during the eutrophication and re-oligotrophication. A threshold was reached around 1980-1985 when cladoceran functionality changed resulting in higher abundance of small-sized planktonic grazers and lower FD and decreased DEL. Long-term development of FD was controlled mainly by bottom-up drivers and is therefore related to ecosystem functioning, i.e., productivity. More spatial and long-term temporal paleolimnological data is required to understand the phenomenon comprehensively. For example, understanding whether the observed pattern in FD and in-lake production is common only during anthropogenic eutrophication process and in large subalpine lakes or if such relationship exists among a geographically wider set of lakes and under natural lake ontogenic development.

Acknowledgments: Funding for this project included the VIOLET and SCUM projects (287547 and 308954) of the Academy of Finland to L. Nevalainen and a Fulbright research award to M. Brown. Interpretation of the sediment chronology was provided by Piero Guilizzoni and Victoria Putyrskaya. We acknowledge the constructive comments by Tomi Luoto and three anonymous reviewers. 
Author Contributions: Meghan Brown and Marina Manca sampled the sediments and pretreated the samples; Liisa Nevalainen, Meghan Brown and Marina Manca analyzed the data; Liisa Nevalainen wrote the paper with comments from Meghan Brown and Marina Manca.

Conflicts of Interest: The authors declare no conflict of interest.

\section{References}

1. Schindler, D.W. The dilemma of controlling cultural eutrophication of lakes. Proc. R. Soc. B 2012, 279, $4322-4333$. [CrossRef] [PubMed]

2. Heino, J.; Virkkala, R.; Toivonen, H. Climate change and freshwater biodiversity: Detected patterns, future trends and adaptations in northern regions. Biol. Rev. 2009, 84, 39-54. [CrossRef] [PubMed]

3. Whitehead, P.G.; Wilby, R.L.; Battarbee, R.W.; Kernan, M.; Wade, A.J. A review of the potential impacts of climate change on surface water quality. Hydrol. Sci. J. 2009, 54, 101-123. [CrossRef]

4. Hooper, D.U.; Solan, M.; Symstad, A.; Díaz, S.; Gessner, M.O.; Buchmann, N.; Degrande, V.; Grime, P.; Hulot, F.; Mermillod-Blondin, F.; et al. Species diversity, functional diversity, and ecosystem functioning. In Biodiversity and Ecosystem Functioning. Synthesis and Perspectives; Loreau, M., Naeem, S., Inchausti, P., Eds.; Oxford University Press: Oxford, UK, 2002; pp. 95-281.

5. Barnett, A.J.; Finlay, K.; Beisner, B.E. Functional diversity of crustacean zooplankton communities: Towards a trait-based classification. Freshw. Biol. 2007, 52, 796-813. [CrossRef]

6. Schleuter, D.; Daufresne, M.; Massol, F.; Argillier, C. A user's guide to functional diversity indices. Ecol. Monogr. 2010, 80, 469-484. [CrossRef]

7. Cardinale, B.J.; Duffy, J.E.; Gonzalez, A.; Hooper, D.U.; Perrings, C.; Venail, P.; Narwani, A.; Mace, G.M.; Tilman, D.; Wardle, D.A.; et al. Corrigendum: Biodiversity loss and its impact on humanity. Nature 2012, $486,59-67$.

8. Vogt, R.J.; Beisner, B.E.; Prairie, Y.T. Functional diversity is positively associated with biomass for lake diatoms. Freshw. Biol. 2010, 55, 1636-1646. [CrossRef]

9. Luoto, T.P.; Nevalainen, L. Climate-forced patterns in midge feeding guilds. Hydrobiologia 2014, 742, 141-152. [CrossRef]

10. Nevalainen, L.; Luoto, T.P. Relationship between cladoceran (Crustacea) functional diversity and lake trophic gradients. Funct. Ecol. 2017, 31, 488-498. [CrossRef]

11. Gregory-Eaves, I.; Beisner, B.E. Palaeolimnological insights for biodiversity science: An emerging field. Freshw. Biol. 2011, 56, 2653-2661. [CrossRef]

12. Nevalainen, L.; Luoto, T.P.; Manca, M.; Weisse, T. A paleolimnological perspective on aquatic biodiversity in Austrian mountain lakes. Aquat. Sci. 2014, 77, 59-69. [CrossRef]

13. Guilizzoni, P.; Levine, S.N.; Manca, M.; Marchetto, A.; Lami, A.; Ambrosetti, W.; Brauer, A.; Gerli, S.; Carrara, E.A.; Rolla, A.; et al. Ecological effects of multiple stressors on a deep lake (Lago Maggiore, Italy) integrating neo and palaeolimnological approaches. J. Limnol. 2012, 71, 1-22. [CrossRef]

14. Marchetto, A.; Lami, A.; Musazzi, S.; Massaferro, J.; Langone, L.; Guilizzoni, P. Lake Maggiore (N. Italy) trophic history: Fossil diatom, plant pigments, and chironomids, and comparison with long-term limnological data. Quat. Int. 2004, 113, 97-110.

15. Morabito, G.; Manca, M. Eutrophication and recovery of the large and deep subalpine Lake Maggiore: Patterns, trends and interactions of planktonic organisms between trophic and climatic forcings. In Eutrophication: Causes, Economic Implications and Future Challenges; Environmental Science; Lambert, A., Roux, C., Eds.; NOVA Science Publishers: New York, NY, USA, 2014; pp. 183-214.

16. Manca, M.; Ruggiu, D. Consequences of pelagic food-web changes during a long-term lake oligotrophication process. Limnol. Oceanogr. 1998, 43, 1368-1373. [CrossRef]

17. Manca, M.; Torretta, B.; Comoli, P.; Amsinck, S.L.; Jeppesen, E. Major changes in trophic dynamics in large, deep sub-alpine lake maggiore from 1940s to 2002: A high resolution comparative palaeo-neolimnological study. Freshw. Biol. 2007, 52, 2256-2269. [CrossRef]

18. Manca, M.; DeMott, W.R. Response of the invertebrate predator Bythotrephes to a climate-linked increase in the duration of a refuge from fish predation. Limnol. Oceanogr. 2009, 54, 2506-2512. [CrossRef]

19. Szeroczyńska, K.; Sarmaja-Korjonen, K. Atlas of Subfossil Cladocera from Central and Northern Europe; Friends of the Lower Vistula Society: Swiecie, Poland, 2007; p. 83. 
20. Rao, C.R. Diversity and dissimilarity coefficients: A unified approach. Theor. Popul. Biol. 1982, $21,24-43$. [CrossRef]

21. Flössner, D.; Krebstiere, C. Kiemen- und Blattfüßer, Branchiopoda. Fischläuse, Branchiura. Die Tierwelt Deutchlands 60; Gustav Fischer Verlag: Jena, Germany, 1972; p. 499.

22. Flössner, D. Die Haplopoda und Cladocera (ohne Bosminidae) Mitteleuropas; Backhuys Publishers: Leiden, The Netherlands, 2000; p. 428.

23. Šmilauer, P.; Lepš, J. Multivariate Analysis of Ecological Data Using Canoco 5; Cambridge University Press: Cambridge, UK, 2014; p. 376.

24. Hammer, Ø.; Harper, D.A.T.; Ryan, P.D. PAST: Paleontological Statistics Software Package for education and data analysis. Palaeontol. Electron. 2001, 4, 9.

25. Oosterbaan, R.J. SegReg: Segmented Linear Regression with Breakpoint and Confidence Intervals. Available online: https: / /www.waterlog.info/segreg.htm (accessed on 18 January 2018).

26. Manca, M.M.; Portogallo, M.; Brown, M.E. Shifts in phenology of Bythotrephes longimanus and its modern success in Lake Maggiore as a result of changes in climate and trophy. J. Plankton Res. 2007, 29, 515-525. [CrossRef]

27. Manca, M. Invasions and re-emergences: An analysis of the success of Bythotrephes in Lago Maggiore (Italy). J. Limnol. 2011, 70, 76-82. [CrossRef]

28. Keilty, T.J. A new biological marker layer in the sediments of the great lakes: Bythotrephes cederstroemi (schödler) spines. J. Gt. Lakes Res. 1988, 14, 369-371. [CrossRef]

29. Branstrator, D.K.; Brown, M.E.; Shannon, L.J.; Thabes, M.; Heimgartner, K. Range expansion of Bythotrephes longimanus in North America: Evaluating habitat characteristics in the spread of an exotic zooplankter. Biol. Invasions 2006, 8, 1367-1379. [CrossRef]

30. Hall, R.I.; Yan, N.D. Comparing annual population growth estimates of the exotic invader Bythotrephes by using sediment and plankton records. Limnol. Oceanogr. 1997, 42, 112-120. [CrossRef]

31. Branstrator, D.K.; Beranek, A.E.; Brown, M.E.; Hembre, L.K.; Engstrom, D.R. Colonization dynamics of the invasive predatory cladoceran, Bythotrephes longimanus, inferred from sediment records. Limnol. Oceanogr. 2017, 62, 1096-1110. [CrossRef]

32. Milan, M.; Bigler, C.; Tolotti, M.; Szeroczyńska, K. Effects of long term nutrient and climate variability on subfossil Cladocera in a deep, subalpine lake (Lake Garda, northern Italy). J. Paleolimnol. 2017, 58, 335-351. [CrossRef]

33. Geller, W.; Müller, H. The Filtration Apparatus of Cladocera: Filter mesh-sizes and their implications on food selectivity. Oecologia 1981, 49, 316-321. [CrossRef] [PubMed]

34. Vijverberg, J.; Boersma, M. Long-term dynamics of small-bodied and large-bodied cladocerans during the eutrophication of a shallow reservoir, with special attention for Chydorus sphaericus. Hydrobiologia 1997, 360, 233-242. [CrossRef]

35. De Bernardi, R.; Giussani, G.; Manca, M.; Ruggiu, D. Trophic status and the pelagic system in Lago Maggiore. Hydrobiologia 1991, 191, 1-8. [CrossRef]

36. DeMott, W.R. Feeding selectivities and relative ingestion rates of Daphnia and Bosmina. Limnol. Oceanogr. 1982, 27, 518-527. [CrossRef]

37. DeMott, W.R.; Kerfoot, W.C. Competition among cladocerans: Nature of the interaction between Bosmina and Daphnia. Ecology 1982, 63, 1949-1966. [CrossRef]

38. Jeppesen, E.; Jensen, J.P.; Amsinck, S.; Landkildehus, F.; Lauridsen, T.; Mitchell, S.F. Reconstructing the historical changes in Daphnia mean size and planktivorous fish abundance in lakes from the size of Daphnia ephippia in the sediment. J. Paleolimnol. 2002, 27, 133-143. [CrossRef]

39. Thompson, P.L.; Davies, T.J.; Gonzalez, A. Ecosystem functions across trophic levels are linked to functional and phylogenetic diversity. PLoS ONE 2015, 10, e0117595. [CrossRef] [PubMed]

40. Amsinck, S.L.; Jeppesen, E.; Landkildehus, F. Inference of past changes in zooplankton community structure and planktivorous fish abundance from sedimentary subfossils-A study of a coastal lake subjected to major fish kill incidents during the past century. Arch. Hydrobiol. 2005, 162, 363-382. [CrossRef]

(C) 2018 by the authors. Licensee MDPI, Basel, Switzerland. This article is an open access article distributed under the terms and conditions of the Creative Commons Attribution (CC BY) license (http:/ / creativecommons.org/licenses/by/4.0/). 